Article

\title{
Auguste Comte and Consensus Formation in American Religious Thought-Part 1: The Creation of Consensus
}

\author{
Kenneth S. Sacks \\ Department of History, Brown University, Providence, RI 02912, USA; Kenneth_Sacks@brown.edu \\ Received: 19 June 2017; Accepted: 4 August 2017; Published: 10 August 2017
}

\begin{abstract}
French intellectual Auguste Comte was the most influential sociologist and philosopher of science in the Nineteenth Century. This first of two articles summarizes his complex life's works and details reactions to them by Transcendentalists and Unitarians, from its American introduction in 1837 until just after the Civil War. Using public speeches and published essays, the article analyzes the ways in which intellectuals supported and criticized Comte's theories. Because he wrote in such abstract and difficult French, criticisms centered not on the nuances of his work, but more superficially on his alleged atheism. These attacks occur because of a variety of consequences of the Civil War that had little to do directly with Comte's philosophy. Instead, Comte was a convenient vehicle for expressing anxiety over a modernism that included an accelerated threat against religion posed by technology and science and the emerging dominance of that secular knowledge in universities. The second article will analyze Comte's influence on later Transcendentalists and other post-Unitarian thinkers.
\end{abstract}

Keywords: Comte; positivism; community of discourse; Unitarianism; Transcendentalism

On 25 August 1911, George Santayana presented to the Philosophical Union at the University of California, Berkeley, his now famous talk, "The Genteel Tradition in American Philosophy." Somewhat under the influence of his Harvard colleagues who had developed pragmatism - the lecture centers on William James - the Spanish philosopher argued that Transcendentalism had proposed the proper epistemology for the prevailing scientific attitudes of his own day:

Transcendentalism proper, like romanticism, is not any particular set of dogmas about what things exist; it is not a system of the universe regarded as a fact, or a collection of facts. It is a method, a point of view, from which any world, no matter what it might contain, could be approached by a self-conscious observer. Transcendentalism is systematic subjectivism. It studies the perspectives of knowledge as they radiate from the self; it is a plan of those avenues of inference by which our ideas of things must be reached, if they are to afford any systematic or distant vistas. In other words, transcendentalism is the critical logic of science. Knowledge, it says, has a station, as in a watch-tower; it is always seated here and now, in the self of the moment. The past and future, things inferred and things conceived, lie around it, painted as upon a panorama. They cannot be lighted up save by some centrifugal ray of attention and present interest, by some active operation of mind ... I regard it as the chief contribution made in modern times to speculation. ${ }^{1}$

Science rejects explanations based on non-human revelation and action-any supposedly divine disruption of nature's harmonic order and laws. Science starts with the individual self's

1 (Santayana 1913, pp. 193-34); discussed by (Capper 1998, pp. 511-15). 
perspective and agency on the material world. It works through induction-hypothesis-testing and trial-and-error-which are the yin and yang of theory and observation. Transcendentalists, often thought of (even by themselves) as idealists, also appreciated this dual approach to consciousness. Although a priori Reason guided the mind, experiential Understanding was essential food for thought. That bipartite epistemology derived from Coleridge's reductive reading of Kant, and it became the intellectual framework for American Transcendentalism.

But toward the end of the Transcendentalist era, the influence of another Continental philosopher, with somewhat similar ideas, helped sustain this dualism and what Santayana called "systematic subjectivism." Auguste Comte (1789-1857), widely considered the first modern philosopher of science, to no small degree figured into the thinking of late Transcendentalism and its fellow travelers in liberal Unitarianism. One of the most public and prolific of the latter, Joseph Henry Allen, in "The Religion of Humanity," observed that:

[S]tep by step, the theological is supplanted by the scientific, the divine by the human view. It is, in other words, a 'religion of humanity' taking the place, in our generation, of a religion of dogma ... The thought of a divine existence, of an infinite will, remains, but only to give life to imagination ... But when it comes to the task of interpretation and instruction and guidance, then it is the lesson of experience and the word of science that we need. History, politics, economy, social statics and dynamics ... these must make the subject-matter of our study, when we seek to follow out any line of practical duty and morals ... (Allen 1880, pp. 57-58).

When Allen titled his article "The Religion of Humanity," he was echoing the phrase coined by Comte, whose theory of positivism began with the question: What, precisely, can humans know? Nothing at all, he answered, that was dictated by traditional metaphysical theological, but only what might be won from rigorous empirical investigation. Science, to Comte, is a "connaissance approchée": through hypothesis testing, it moves ever closer to truth without ever fully reaching it. Science investigates a world without divine intervention, a world created, understood, and categorized by the human mind.

Harriet Martineau, a distant British relative of Ralph Waldo Emerson's and well-known to American Transcendentalists, translated and edited Comte, rendering his words thus: "If it is true that every theory must be based upon observed facts, it is equally true that facts cannot be observed without the guidance of some theories. Without such guidance, our facts would be desultory and fruitless; we could not retain them: for the most part we could not even perceive them" (Comte 1853, pp. 5-6). The constant reassessment of theory based on observable fact-broadly within the framework of several earlier thinkers, such as Locke, Kant, Rousseau and Scottish Common Sense-meant that, for Comte, scientific knowledge was not absolute. And therefore, science could not have the final word. Rather, science was subordinated to and guided by human perspective expressing social needs. ${ }^{2}$

Charles S. Peirce, an essential fin de siècle American thinker, acknowledged that Comte had made the proper connection in locating science in relationship to the human mind: "the sciences may be arranged in a series with reference to the abstractness of their objects; and that each science draws regulating principles from those superior to it in abstractness, while drawing data for its inductions from the sciences inferior to it in abstractions" (Peirce 1896). Or in the words of Comte's famous prescription: "from science comes prevision: from prevision comes action" (Comte 1853, vol. 1, p. 20). Observes contemporary authority on Comte, Michel Bourdeau:

Founding social science therefore constitutes a turn in the history of humanity. Until then, the positive spirit was characterized by the objective method, which works its way from the world to man; but as this goal has now been reached, it becomes possible to invert

2 Unlike the Neo-Positivists of the Twentieth Century: see (Bourdeau 2014). 
that direction and go from man to world, to adopt, in other words, the subjective method, which so far had been associated with the anthropomorphism of theology (Bourdeau 2014).

Comte's theory of knowledge, then, aligned with that of many practitioners of Transcendentalism and pragmatism.

Outside of his contributions to science studies, Comte's work is not today well known in America. But in the latter part of the Nineteenth Century, Comte was a force to be reckoned with. Heavily promoted by John Stuart Mill in his System of Logic (1843), ${ }^{3}$ the French philosopher was far more famous than such contemporary fellow utopianists and sociologists as Charles Fourier, comte de Saint-Simon, and Karl Marx. (According to Google Ngram, the latter two finally passed Comte in American literature citations in the 1890s; of utopianists, only Robert Owen attracted more interest than Comte before 1860, as measured by citations.) Considered among the most influential nineteenth century theorists of the progress of civilization (Bowler 2003, p. 99), Comte is also credited with inventing the modern meaning of the term "sociology", which he deemed the most complex and useful of the sciences. ${ }^{4}$ A century later, Isaiah Berlin testified that Comte's achievements, coming at a moment of enormous expansion of scientific knowledge, were monumental:

Our view of the natural sciences, of the material basis of cultural evolution, of all that we call progressive, rational, enlightened, Western, our view of the relationships of institutions and of public symbolism and ceremonial to the emotional life of individuals and societies, and consequently our view of history itself, owes a good deal to his [Comte's] teaching and his fame ... Above all he grasped the central issue of all philosophy-the distinction between words (or thoughts) that are about words, and words (or thoughts) that are about things, and thereby helped to lay the foundation of what is best and most illuminating in modern empiricism; and, of course, he made a great mark on historical thinking (Berlin 1954, pp. 3-4).

Auguste Comte began his career as secretary to Saint-Simon, who, like other early utopianists (such as Charles Fourier, whose work had an important influence on Transcendentalist George Ripley and Brook Farm), wished to create an exalted place for the working class within the harsh conditions of the early Industrial Revolution. The deeper structure that framed these utopian discussions was the Enlightenment sense of the emerging individual and the perfectibility of society, articulated especially by philosophers Nicolas de Condorcet and Jean Jacques Rousseau. Convinced that Saint-Simon was appropriating his own ideas, Comte left his employ in 1824. Not for the last time, Comte displayed erratic behavior, at times probably suffering from mental illness. Too, Comte never shook off the trauma of the French Revolution, instilling his life and work in "anticipatory conservatism" of future social disruption.

Comte wrote prolifically, with two encompassing clusters of works defining his intellectual directions. Soon after striking out on his own, Comte begin publishing the six volume series, The Course in Positive Philosophy (hereafter, Course). ${ }^{5}$ Harriet Martineau's liberal abridgement and translation, published in 1853, transformed British understanding and ignited the popularity of Comte, whose work, to those who didn't want to read six volumes in challenging French, had previously been largely represented by generally negative reviews (Cashdollar 1989, p. 57). A bit later Comte applied his sociological principles to the reorganization of society in the four volume System of Positive Polity, or Treatise on Sociology, Instituting the Religion of Humanity (hereafter, System) ${ }^{6}$.

3 See also (Cashdollar 1989, pp. 28-38).

4 Emmanuel Joseph Sieyès coined the term in 1780, but Comte seems to have introduced it independently and with different intent. Comte had originally used "social physics," but when others, especially scientist and statistician Adolphe Quetelet, began appropriating the phrase, Comte turned to using sociology.

5 Originally, Cours de philosophie positive $=($ Comte 1830-1842).

6 Originally, Système de politique positive, ou traité de sociologie instituant la religion de l'Humanité = (Comte 1851-1854). 
But the two major efforts probably represent a continuum of thought, since as early as 1822 Comte announced the connection between his scientific and political visions. ${ }^{7}$ Comte's guiding concern was that intellectual disorder creates social disorder. The only way to guard against ideology that produces the arbitrary actions of kings or the erratic zeal of revolutionaries was to insist that social theory be as grounded in positivist observation as are the sciences (Comte 1975, pp. xxxi-xlviii). The interleafing of the sciences and social sciences guarantees that political life is as tightly structured as the natural world (Comte 1975, p. lxii).

In the Course, Comte outlined three broad stages of human (Western) thought in relationship to the material world. The earliest was the theological (which had its own subdivisions of fetishism, polytheism, and monotheism) in which the inexplicable facts and events of nature were attributed to the supernatural and to divine intervention. But notably, the development of monotheism in the final phase of the theological period also helped create the scientific mind: "Monotheism ... was willing that explorers should study the details of phenomena, and even disclose their secondary laws, which were at first regarded as many manifestations of supreme wisdom." And so, reciprocally: "Thus it was that monotheism, which owed its existence to the first stirrings of the scientific spirit, was itself indispensable to its further progress..." (Comte 1853, vol. 2, pp. 407-8).

The second stage, the metaphysical or transitional age, began in the Fourteenth Century and was marked by the rise of industry, culminating in the French Revolution and a growing belief in reason and human rights. In this stage, humans relied on their own abstract reasoning, which, rather than divine intervention, organized the natural or factual world. The current third and final stage of human history is the time of modern industry and is called the Positive era. In this, the human mind and therefore its scientific systems of thoughts are no longer focused on determining origins or in resolving phenomenological anomalies but now are committed to understanding through observation and reasoning the larger laws that govern them. Precisely because these laws are based on human observation and understanding, they are relative (determined through the practice of continuous hypothesis-testing) rather than absolute (created by the earlier theological habits). It becomes, therefore, the very way that science gets structured, and the precise connections among these different scientific disciplines determines their predictive value (De Groot 2015).

In this final, positivist phase, the social sciences become "scientific" as well (Pickering 1993-2009, vol. 1, pp. 633-78), with the Course including three volumes on the sciences and three on the social sciences-all "positive" sciences. This pyramid of scientific knowledge is topped off with the foundations of the "social physics"—sociology—conforming to the later assessment of pragmatist Charles Peirce cited above, that "each science draw[s] data for its inductions from the sciences inferior to it in abstractions." Although the several sciences had their own independent existence, from a subjective epistemology they were interdependent and linked in a chain, from bottom to top, in the service of reorganizing humanity to its optimal state (Simon 1963, pp. 5-6). The belief that the natural and social sciences were progressing through structured and ever enlightened stages encouraged Comte to believe that humanity was now constantly moving toward its own enlightenment, driven by the continuous clarification of the sciences and social sciences through hypothesis-testing (Pickering 1993-2009, vol. 1, pp. 691-710). ${ }^{8}$

The application of both scientific and the social scientific knowledge for the betterment of society was one part of Comte's eventual program. The other was the reinterpretation, indeed, the reinvention, of religion. Since David Hume's Dialogues Concerning Natural Religion in 1779, religious belief based on miraculous events had come under persistent attack. ${ }^{9}$ Science gradually became viewed as the

(Comte 1822) with (Comte 1975, p. xxxv).

8 The connection between biology and social theory had been on solid footing since Rousseau understood the origins and development of society evolving out of nature. But Comte saw society as not dependent on biology, but rather that sociology was the culmination for scientific inquiry: (Greene 1969).

9 On Hume's atheism, see most recently (Gottlieb 2016). 
destroyer of the supernatural religious miracle, as fellow Scot Thomas Carlyle noted in his 1840 On Heroes, Hero-Worship, and the Heroic in History: "There needs to be, as it were, a world vacant, or almost vacant of scientific forms, if men in their loving wonder are to fancy their fellow-man either a god or one speaking with the voice of a god." But even as he believed religion to be rooted in ignorance and fear, Hume did appreciate its social purpose. This is effectively the value Comte reflected in his Religion of Humanity, proposing a highly elaborate system of public and private sanctification without a godhead and in the service of moral behavior and social improvement.

After the death in 1846 of his great platonic love, Clotilde de Vaux (who could not obtain a divorce from her husband), and at least somewhat in pious veneration of her memory, Comte introduced a philosophy of the heart, his Religion of Humanity. Contained mainly within his System and his Catechism of Positive Religion (1852), ${ }^{10}$ its guiding principle was altruism. And, although altruism is also promoted in organized, theologically-based religion, Comte felt that veneration of an anthropomorphic deity undermined individual altruistic tendencies (Edwin 1931, p. 10). Comte's thinking was similar to that of the contemporary Young Hegelians, who argued that belief in a supernatural force deprived humanity of its finest attributes, such as altruism, which were instead idealized and ascribed to the godhead. But unlike the Young Hegelians and other atheists (such as Ernest Renan), Comte did not, at least at times, explicitly deny the possible existence of a god. Rather, he argued that there was no-and there cannot be any-positive knowledge of a deity. Comte and followers effectively worshipped Humanity-the best qualities of themselves. "What New England readers like [Joseph H.] Allen wanted and did not find in [Young Hegelian Ludwig] Feuerbach but rather in Comte," observes Elisabeth Hurth, "was an ethics rooted in the concrete situation of individual man, an ethics applicable to human behavior" (Hurth 2007, p. 118).

With sociology and (as the fledging field developed) anthropology the highest forms of knowledge, Comte identified religious ritual as both a human need and, having experienced the rippling uncertainties of the French Revolution, an instrument for maintaining social order. What Comte proposed, as Friedrich Engels famously labeled it, was "Catholicism without Christianity" (Marx and Engels 1975, p. 453). Sociology was its highest truth and Comte himself the High Priest or Supreme Pontiff overseeing a priesthood and an elaborate system of public and private prayers (not requests for divine favors, but as expressions of love) with seven sacraments tied to life cycle events, culminating in a sort of sainthood—an "absorption into history" - three years after the individual's death. Each day and month of the new calendar was named for a deceased great individual. Throughout this closely regulated life cycle, citizens would rededicate themselves to service (McGee 1931, pp. 9-38). Melding nineteenth-century rationalism with long standing religious tradition, Comte demanded that, along with venerating the New Supreme Being, initiates acknowledge Earth (the Grand Fetish), Cosmic Space (the Grand Milieu), and the Virgin Mother. ${ }^{11}$

If the earlier Course continued to command admiration, the later System provoked ridicule and enmity. John Stuart Mill, originally infatuated with Comte with whom he frequently corresponded, could sharply distinguish between the sociologist of the Course and the muse of the System who promoted this highly restrictive secular religion as the summa of intellectual and moral achievement. ${ }^{12}$ Mill referred to Comte's System as "a despotism of society over the individual surpassing anything contemplated in the political ideal of the most rigid disciplinarian among the ancient philosophers" (Mill 1848, p. 12). Isaiah Berlin, so complimentary of Comte's scientific accomplishments, refers to: "His grotesque pedantry, the unreadable dullness of his writing, his vanity, his eccentricity, his solemnity, the pathos of his private life, his insane dogmatism, his authoritarianism, his philosophical fallacies, all that is bizarre and utopian in his character and writings ... " (Berlin 1954, p. 4). A contemporary,

10 = Catéchisme positiviste .

11 Implying parthenogenesis; perhaps reflective of his sexless relationship with Clotilde de Vaux: see (Wernick 2000, p. 3, n. 8). On his gynolatry, see (Wernick 2000, p. 23; Pickering 1993-2009, vol. 3, pp. 312-94).

12 (Mill 1865); see also (Forbes 1975, pp. 17-18). 
otherwise somewhat sympathetic, scholar called Comte's System “organized idolatry ... It was, like Comte himself, an easy-to-satirise victim of its own rigidities, archaisms, and inflated ambition [and] the ramblings of a ruined mind." (Wernick 2000, pp. 1, 5, 24).

Comte's System, however, was not just religious reorganization; it also required a fundamental recommitment to republican values of virtue, determined by civil authority. Because to him the innateness of the benevolent sensibilities was as scientifically proven as was the law of gravity, duties were based on social responsibility, not on desire for personal salvation (Pickering 1993-2009, vol. 2, pp. 344-5). With humanity now in this third and ultimate, positivist stage, Comte demanded that society take responsibility for promoting its most successful manifestations, including public funding for science. In protecting and integrating the complex elements of industrialized society, government must rely on the social sciences for the ultimate moral truths. For example, Comte believed that viewing economic forces in isolation or as pure theory only served to justify individual greed. Rather, social consequences of all economic activity needed also be considered.

Although he didn't lived long enough to develop a complete moral code to complement his imagined religious community, Comte ambitiously believed his moral principles would be embraced world-wide, eventually breaking down national borders. The Earth belonged to everyone, and the nationalism that had evolved in previous centuries was an accident of history. As a way of eliminating nationalism based on current affinities, he proposed dividing the world into seventy republics and suggested that France might first deconstruct itself into nineteen "intendances" (Pickering 1993-2009, vol. 3, p. 15). A committed cosmopolitan, Comte criticized European colonizing efforts and expressed special respect for Islam (which helps explain why Young Turks became positivists).

Humanistic societies founded on his principles existed in England, France, Germany, the United States, Turkey, Mexico and Brazil (Hale 1989; Trindade 2003; Plé 1996; Simon 1963). Comte was the first western philosopher translated into Japanese (Pickering 1993-2009, vol. 3, p. 578). Comte also predicted that India could be converted to positivism within thirteen years, and British missionaries spread their gospel there, with very limited success (Forbes 1975). Despite its roots in France, it was in England, in fact, that positivism found its most enthusiastic following.

Coming at the high stage of the Industrial Revolution and in the throes of Darwinism and the beginnings of social Darwinism, positivism promised to address many conflicting needs in Great Britain. Followers saw a way to strike a strong alliance with the trade unions. Positivism also coincided with Victorian values of moral duty and personal restraint, along with a desire to move away from traditional metaphysical theology:

The Religion of Humanity aimed to settle the conflict between the friends of science and those of religion by means of a religion which was not only scientific, but which afforded an opportunity for science itself to become religious by concentrating its energies upon human welfare. It sought to dissolve the struggle between employers and workmen by having each group consider the best interests of the other, and, indeed, of society itself (McGee 1931, pp. 42-43).

And because all political and social action had to consider its effects on all participants, positivists also supported a modified feminism and opposed imperialism (McGee 1931, pp. 63-92). With the ascendency of the altruistic tendency and social responsibility, world peace and social stability were, followers believed, within reach (Hawkins 1997, p. 54).

Besides Mill, who expressed initial though limited enthusiasm, a significant number of prominent British intellectuals signed on, to greater or lesser degrees—some attending positivist events, some endorsing the philosophy through their own writings, some supporting the work financially. These included: the chief organizer of positivism in the UK, Oxford don Richard Congreve, along with three of his Wadham College colleagues; Cambridge philosopher Henry Sidgwick; philosopher George Henry Lewes, who traveled to France to meet Comte and eventually published in 1853 Comte's Philosophy of the Sciences: Being an Exposition of the Principles of the Cours de Philosophie of Auguste Comte; 
and therefore, because of her celebrated relationship with Lewes, also Mary Ann Evans (George Eliot), who by 1859 was known as one of the most fervent of all Comteans in the UK; polymath (and father of Virginia Woolf) Leslie Stephen; distinguished Classicists George Grote and Gilbert Murray; and perhaps the most significant convert, the great socialist and activist Annie Besant, who wrote Auguste Comte; his Philosophy, his Religion, and his Sociology, calling the French sociologist "the greatest thinker of the century."

Observes Christopher Kent:

[In the 1850s and 1860s] Comtism met the anxieties of classically-educated, amateur-oriented intellectuals by providing a scientifically sanctioned blueprint of the future which assured their continued relevance despite the increasing industrialization, specialization, and democratization of society. The nineteenth century produced no more explicit and comprehensive statement of intellectual populism. It could well be argued that the remarkable thing about Comtism was not that it attracted some support in England but that it did not attract more (Kent 1978, p. xiii).

Among the most significant dissenters was Herbert Spencer, whose broader views coincided in several ways. But as a passionate advocate of a free society and proponent of social Darwinism, he expressed more opposition than agreement with the Religion of Humanity. ${ }^{13}$

Nor was British positivism confined to the intellectual elite. In 1873, Charles Maurice Davies recounted witnessing a positivist Sunday School:

I found the [small] school quite full ... Many members of trades' unions attend in the evening ... They seemed to be all bone fide working men around me; and there were a good many who looked like working women too: many who might have been decent domestic servants spending their "Sunday out" in that most unlikely of all places (Davies 1876, pp. 426-27).

The service was led by Congreve, who preached that "We have for the time being eliminated the name of God; but there is no reason why in process of time it should not be replaced, though standing, of course, as the representative of a new idea, namely, Humanity." There were a number of other positivist groups in London, as well as in Manchester, Liverpool, and Newcastle-on-Tyre (Forbes 1975, pp. 27-30). But obscurities in the philosophy and its highly unorthodox religion tempered enthusiasm. When Davies comes to describe the philosophy, he takes refuge in merely quoting the texts: "the process by which the Positive Philosophy passes into the Religion of Humanity is so complicated and delicate, that I feel my best plan will be simply to transcribe a few extracts from Mr. G. H. Lewes's 'History of Philosophy' and refer my readers to that work... " (Davies 1876, p. 430). Ambiguities and misunderstandings—especially over whether Comte was an atheist—would plague positivism's reception in the United States.

Visiting the U.S. in 1851-1852, French philologist Jean-Jacques Ampère noted how Fanny Wright's atheism was anathematized there, adding:

I must say, however, that the Philosophie positive of M. Comte which, under a serious and scientific form, arrives at the negation of all religion, even of natural religion, is fairly often read in America, where perhaps it is accorded more attention than in France. I have heard pious [American] men speak of it with a certain esteem. The name of a Philosophie positive should be pleasing in the positive country par excellence ... ${ }^{14}$

Ampère's point is that Comte's positivism is compatible with the material culture of industrializing America. Indeed, Comte himself thought his system would appeal to the wealthy and

13 (Simon 1963, pp. 12-13, 172-219); Besant quotation on p. 232. Also (Kent 1978, pp. 84-100).

14 (Ampère 1855, vol. 1, pp. 364-65). My translation. 
powerful as a method of providing social stability against the threats of socialism (Pickering 1993-2009, vol. 2, pp. 537-38). As early as 1816, the eighteen-year-old Comte thought his future lay in attending a polytechnic school being considered by the U.S. Congress. When construction of the new institute was delayed, Comte gave up his immediate hope of immigrating to America. But it did not end his infatuation with the new world. His so-called "American mirage"-the belief in the particular virtues of Benjamin Franklin (Comte's "Socrate moderne"); the promises of individual liberty enshrined in its Constitution, especially those which guaranteed separation of church and state; the sense that America was a new society that could be made from scratch-all helped inspire his future utopian plans. He held out hopes that American workers in the largest cities would embrace the System and even envisioned a separate positivist state of Long Island (Hawkins 1938, pp. 210-12). But as he began developing his philosophy, he grew skeptical of an America where there flourished individual reason, Protestantism, and particularly slavery ("une monstruosité sociale"). The only hope for the new country would be to embrace his own philosophy whole cloth (Hawkins 1936, pp. 13-14).

Despite Comte's unmet aspirations, Ampère's observations of the early 1850s were accurate. By then, and certainly helped by the widespread enthusiasm for positivism in the UK, American intellectuals were engaged in significant discussion and debate over Comte. But much of that discussion was driven by confusion and fear. Even in his own time, it was difficult to appreciate precisely where Comte stood of certain essential ideas. It took Comte nearly his entire intellectual life to develop fully his positivist philosophy, and he frequently conveyed to friends views apparently at odds with what he had written.

The text itself produced its own challenges. American philosopher Joseph H. Allen, largely favorable to positivism, characterized Comte's writings as "unreadable French" (Allen 1851, p. 175). Harriet Martineau, explaining why she felt compelled to translate and abridge his work, acknowledged the problem:

[Comte's work] is in the form of lectures, the delivery of which was spread over a long course of years ... M. Comte's style is singular. It is at the same time rich and diffuse. Every sentence is full fraught with meaning; yet it is overloaded with words. His scrupulous honesty leads him to guard his enunciations with epithets so constantly repeated, that though, to his own mind, they are necessary in each individual instance, they become wearisome... (Comte 1853, vol. 1, pp. vi-vii).

As a result, readers and critics shied away from reading the full text, and the general concept of positivism effectively became a meme, just as the essential thoughts of Locke or Kant had earlier: something that stood for a broad sensibility that was often not understood in its details. Charles Cashdollar, who has produced the most careful study of the reception of positivism in Britain and the U.S., observes: "Normally positivism was allowed to stand as an emblem for modern thought-that vague and imperfectly understood collection of ideas from which conservatives sought deliverance and with which liberals hoped for peace ..." (Cashdollar 1989, p. 181).

And yet, while in some ways Comte broadly represented a modernity encompassing nationalism, the Industrial Revolution, and rapid scientific and technological advances, in other ways his thoughts stood against those very forces. Because, even as Comte attempted to lead epistemology into the future, he insisted on a utopian vision of society which, while cosmopolitanism and anti-nationalistic, imposed a rigid social structure to insure class distinctions and a political stability the French Revolution had threatened. Forward thinkers, who might champion the empirically-based epistemology in order to eliminate the need for biblical support and metaphysics, could still find Comte's political solution regressive-indeed, repulsive—on social grounds. In the end, for most intellectuals Comte's controversial social solutions were nearly impossible to disentangle from his contributions to sociology and science theory.

Just as there is no single (say) Plato, Wittgenstein, or Foucault, and just as near the end of his life Marx famously proclaimed that he was no Marxist, there were many Comtes that meant different 
things to different people. Among modern scholars, Trevor Pearce refers to positivism as offering a "big tent" (Pearce 2015, p. 443), and Gillis Harp calls the philosophy a "spectrum" (Harp 1995, p. xii). Comte's contemporary, John Stuart Mill, perhaps reflecting on his own plight on being publicly associated with aspects of positivism, wrote in 1865 that:

though the mode of thought expressed by the terms Positive and Positivism is widely spread, the words themselves are, as usual, better known through the enemies of that mode of thinking than through its friends; and more than one thinker who never called himself or his opinions by these appellations, and carefully guarded himself against being confounded with those who did, finds himself, sometimes to his displeasure, though generally by a tolerably correct instinct, classed with Positivists, and assailed as a Positivist (Mill 1865, p. 2).

Mill's defensive response demonstrates how politicized and misunderstood Comte's positivism quickly became.

Complex ideas expressed and modified over a lifetime and in a foreign language are naturally apt to be broadly (mis)interpreted and to fill widely varying needs within different social networks. David Hollinger coined a helpful descriptor that could be applied to this process, referring to the formation of "communities of discourse." Such communities can be highly elastic, with members aligning by varying degrees of intellectual agreement and social affinity (Hollinger 1980, p. 43). Because this study focuses primarily on Unitarians and post-Unitarians of eastern Massachusetts, many of whom self-identified with the Transcendentalist tradition and who therefore shared a common intellectual and social heritage, community of discourse is a helpful way of understanding their interpretations of positivist philosophy.

Because his work presented a challenging and complex package of thoughts-from epistemology to religion to social reorganization-Comte's positivism is a useful lens through which to view how these developing communities of discourse responded during the tumultuous post-Civil War period through the creation of consensus. My main point is to examine how a foreign idea gets "processed" within a broadly homogeneous group of intellectuals to concretize conformity of thought: in this case, oppositionally to Comte, but in that very process incorporating important aspects of his positivism in the construction of their own ideas. Transcendentalism, as Santayana argued, set the stage for pragmatism. So, any study of how Transcendentalists and liberal Unitarian affiliates evolved or reacted to intellectual currents also helps shed light on some of the elements of formative discourse that subsequently surrounded pragmatism.

When it came to a writer as capacious as Comte, this shared discourse of response might produce several layers of meaning. For example, two of the most prominent members of the Metaphysical Club (below), William James and Charles Peirce, wrote against positivist philosophy. And yet careful readings of their work show that they, too, reflect its influence (Croce 1995, p. 203; Pearce 2015, p. 463). Another member of that club, the effervescently brilliant, if short-lived Chauncey Wright, denied any affection for Comte, writing a friend, "I never read Littrés 'Life of Comte,' and I doubt whether I should sympathize with his interest in his subject enough to enjoy it" (Wright 1878, p. 211). And yet again, there is demonstrable positivist influence to his work (De Groot 2015). Even with such articulate thinkers as Metaphysical Club members, their very social attachments may well have shaped the uniformity of public criticisms while occluding possible individual philosophical sympathies to Comte.

To a very great extent, then, Comte's overall reputation discouraged a dispassionate engagement with his work. Confusion especially reigned over the perception that Comte was an atheist, and, if that were so, what it meant to a tightly-bound Massachusetts intellectual clerisy struggling to live up to both Unitarian and post-religious beliefs. Social affinity produced a high degree of common language that might be at odds with personal thought. While simultaneously feeling the social need to denounce Comte, many indirectly absorbed his philosophy through the connections within those very same discourse communities. 
Brook Farm in its final, Fourierist phase being the most prominent example, ${ }^{15}$ Transcendentalists were inherently sympathetic to utopian visions of society. Virtually simultaneously with their reading of Fourier, Transcendentalist William Henry Channing (nephew and ward of the most famous Unitarian of the day, William Elery Channing) took great interest in Comte's work. Responding in 1879 to Frederic Harrison, Channing recollected that the Course was available to him almost immediately in 1837:

I became a student of Comte from about that time of the publication of the first volume of his Cours de philosophie positive. And as each of the volumes successively appears it was early read and earnestly discussed with my friends Theodore Parker, George Ripley, and O.A. Brownson, till 1854, when I came to England. Since that era, with the exception of some of his strictly mathematical treatises, every word of Comte so far as known to me has been conscientiously studied. ${ }^{16}$

And yet, despite calling Comte "the most thoroughly scientific intellect now on the planet," (Frothingham 1886, p. 244; Pickering 1993-2009, vol. 2, pp. 528-29) an assessment shared by other Unitarians who saw merit in the Course and interpreted Comte's altruism as a version of Christian love, Channing, like other Unitarian colleagues, came to oppose Comte's System and his Religion of Humanity (Cashdollar 1989, pp. 98-99; 121-3).

Along with Ralph Waldo Emerson, Theodore Parker was among the most highly respected of the early Transcendentalists. Parker, "who showed the greatest and most sustained interest in positivism," 17 produced the first book in the English-speaking world to borrow significantly from Comte (in 1842, a year before Mill published System of Logic). Parker's A Discourse of Matters Pertaining to Religion drew on the French philosopher in support of the innateness of the religious impulse (Pickering 1993-2009, vol. 2, p. 529). Importantly, he both acknowledged and simultaneously side-stepped Comte's purported atheism: "He glories in the name [of Atheist], but in many places gives evidence of the religious element existing in him, in no small power," wrote Parker (1865, p. 31, n. 2). And elsewhere, when referencing Comte in attacking an anthropomorphized godhead, he appears to lay the blame for Comte's atheism on organized religion: "[Comte] asks entire Freedom for human nature ... And if the Christian Church had granted this freedom there would have been no atheism" (Parker 1867, p. 40). But he was equally critical that Comte saw persistent monotheism as a reflection of social decline (Grodzins 2002, p. 279), and, writing to Joseph Henry Allen (who was largely favorably disposed to positivism) in 1851, he called Comte "able, dull, materialistic, and ill-natured, and has made a book of sterling merit" (Weiss 1864, vol. 1, p. 381). For Parker, Comte's allure was his progressive utopianism through the three essential phases of human mentality, his cosmopolitanism based on social justice, and his denial of an anthropomorphic godhead. And certainly Parker drew on Comte's claim that theory precedes observation and that hypothesis-making-which is largely based on instinct-is a necessary precondition to determining facts (Comte 1975, p. xxxvii).

These same beliefs attracted others associated with early Transcendentalism. A strong follower of Comte's positivism, the lawyer Horace Binney Wallace met Julia Ward Howe and inspired her with his enthusiasm. Howe later heard her minister Theodore Parker lecture favorably on Comte, and, following Wallace's suicide, she studied positivism with Parker, though there is nothing in her own work reflecting its direct influence (Pickering 1993-2009, vol. 2, pp. 534-36; Cashdollar 1989, pp. 101-4). Similarly, Lydia Maria Child seems to have discussed Comte with Parker, and, although a contemporary reviewer argued that her The Progress of Religious Ideas through Successive Ages (1855) drew directly on Comte, Child never did explicitly acknowledge his influence. ${ }^{18}$ A third women

15 Most recently, (Gura 2017, pp. 52-56).

16 (Hawkins 1936, pp. 14-16), quoting Channing's letter to Frederic Harrison from Octavius Brooks Frothingham, in (Frothingham 1886, p. 373).

17 (Cashdollar 1989, p. 95). Parker may actually have introduced Channing to Comte's work, rather than as Channing introducing Parker, as Channing claims: (Cashdollar 1989, p. 94, n. 1).

18 (Hawkins 1938, pp. 100-2); also (Pickering 1993-2009, vol. 2, p. 530) and (Cashdollar 1989, p. 98). 
associated with Transcendentalism and more engaged in the debate was Elizabeth Palmer Peabody. Peabody ordered the Course for her famous Boston book store and in 1858 reviewed Catechism of Positive Religion in the Christian Examiner-the most important Unitarian outlet. Although disagreeing with the positivist proposition that the noumenal is unprovable, she broadly agreed with the belief of the Religion of Humanity that, "It is the gradual appreciation of this necessity [to look for spirituality within collective humanity] which is giving a broader range to the theology of our day" (Peabody 1858b, p. 248).

Unitarian Joseph Henry Allen was perhaps the most prominent New England authority on Comte's positivism. Grandson of the elder Henry Ware and acquaintance of Emerson's (Emerson 1990, vol. 7, p. 247), Allen first learned of positivism as a student at Harvard when James Walker (below) was giving the Lowell lectures on natural religion (Allen 1851, p. 174). As a Unitarian minister in Washington D.C. in 1849, he composed an article on Comte that he asked Parker to publish, but Parker replied that Allen would be better served by submitting it to the widely-circulating Christian Examiner ${ }^{19}$ In this 1851 piece, Allen announced that the pyramid of knowledge "is nothing less than the recasting of the whole system of modern thought and knowledge ... " (A's emphasis) Indeed, "Hardly a page or a line is without its fertile suggestion, and its traces of close and profound thought" (Allen 1851, pp. 178, 184).

But toward Comte's religious ideas, Allen displayed great ambiguity. Contrary to a widespread belief, Allen argued, as had Parker, that Comte does not urge a "vulgar atheism" (Allen 1851, p. 195) and "repudiates the name atheist ... as he would religionist." To the extent that he suggests that theology should not be the basis of the social organization of society, Allen (1851, p. 196) agrees. But in Comte's "preferring to consider every question as if there were no God (Allen 1851, p. 197; A's emphasis), Allen sees despair. To Allen, "when the Fact becomes a Law, a Tendency, a conscious Purpose, and a Life, then to us it necessarily becomes Divine." (Allen 1851, p. 198) That is the essence of Allen's long dispute with Comte. Allen, very much in the tradition of Emerson in "The American Scholar" and The Divinity School Address, believes that: "The religious mind transmutes the 'fixed facts,' of whatever order, into food and stimulus for its devotion. The 'theological state' is not deserted and left behind ... but is taken up and carried along with the progress of the mind, and made to harmonize with the successive stages of development" (Allen 1851, pp. 200-1).

When it came to atheism, Allen thought that the Young Hegelians, especially Feuerbach (who directly opposed supernaturalism), were far more dismissive of the possibilities of religion than was Comte. To Allen, positivism doesn't assume there was no god, but rather that there is no, and cannot be, any positive knowledge of a deity; it was "scientific atheism" and did not explicitly deny the existence of a god (Hurth 2007, p. 118). Allen labeled Feuerbach's belief "Atheistic Nihilism," while Comte's notion of deity was still organic and resided in the nature of humanity, which might still come to a belief in the divine (Allen 1857b, p. 437).

Although certainly not true for all members of his circle (below), Allen held out hope for Comte. In (Comte 1852), he contacted Horace Binney Wallace, whom Comte had acknowledged in the Course, and asked whether they might establish a positivist school or society in the U.S. But Wallace discouraged any formal organization and urged that Allen just spread the word. Allen and Wallace stayed in contact until Wallace's suicide (Cashdollar 1989, p. 108). Later, in 1855, Allen visited Comte in Paris attempting to determine Comte's views on the existence of God (Cashdollar 1989, p. 109). Allen felt sufficiently satisfied that Comte allowed for human belief in a divine presence that, in his 1857 review of the System, he described Comte as "a man singularly combining the most absolute need of a religious faith, with the most entire negation of its generally received intellectual postulates" and therefore pronounced that, "The Deity it [positivism] dethrones is simply an idol" (Allen 1857a,

19 (Cashdollar 1989) for Allen-Parker correspondence. 
pp. 23, 31). Allen somewhat admired Comte's educational system, but not the morals he imposed on family life or his Catholic-like secular religion which manifested a lack of moral freedom.

Throughout his career, Allen served as a bellwether for the concerns of his peers that Comte envisioned a society of atheists. Allen became editor of the Christian Examiner (1863-1865) and the Unitarian Review (1887-1891: (Cashdollar 1989, pp. 104-10)), and found his way to Harvard (1878-1882), succeeding Frederic Henry Hedge, who recommended him as lecturer in Ecclesiastical History (Williams 2014, vol. 2, p. 118). Allen continued to believe that, "Christ signifies not the historic individual, but the Divine Life indwelling in the soul of man, and making the highest life of mankind at large" (Allen 1891, p. 208). Allen gave primacy to Jesus and called himself a Christian even while denying Jesus's divinity, believing in the sanctity of "the soul, [which has] close relation to the Infinite Source of life, bear[ing] always within it the germ of good" (Allen 1844, p. 166). And at Harvard he defended Comte's religious sentiment, recollecting:

"I am no atheist," Comte protested vehemently: he said it me about two years before his death. An atheistic theory of the universe he held to be the mere dotage of metaphysical vanity. If you will have a theory of existence, he said, an Intelligent Will is the best you can have. In his unique fashion, he held it the great work of his life to restore to Religion its supremacy in all matters of conduct; the very phrase "religion of humanity" is claimed as his invention (Allen 1882, p. 158).

That Allen needed to make the case against recurrent assertions to the contrary is a reflection of a deeper emotional response to Comte's work. Despite his harsh criticisms of the System, the far more famous John Stuart Mill had also felt compelled to put to rest the charge of atheism:

[Comte] indeed disclaimed, with some acrimony, dogmatic atheism, and even says (in a later work, but the earliest contains nothing at variance with it) that the hypothesis of design has much greater verisimilitude than that of a blind mechanism. But conjecture, founded on analogy, did not seem to him a basis to rest a theory on, in a mature state of human intelligence. He deemed all real knowledge of a commencement inaccessible to us, and the inquiry into it an overpassing of the essential limits of our mental faculties (Mill 1865, p. 15).

Mill knew this well, because Comte had earlier written him, directly asserting, as he had to Allen, that atheists were regressive thinkers who claimed to know something that was unknowable. ${ }^{20}$

The writings of Parker and Allen demonstrate how important was the question of atheism among New England intellectuals in evaluating Comte's larger contributions to science and society. In its earliest days of separation from Congregationalist Trinitarianism, Unitarianism had to defend itself from the charge of atheism (Gilman 1830). But, once established, Unitarians in turn viewed its most liberal offshoot of Transcendentalism as a manifestation of the same. Indeed, in 1841 Frederic Henry Hedge, considered the initial theorist of American Transcendentalism, distanced himself from Transcendentalist friends for fear of being accused of atheism (Hunter 1980, pp. 196-98). Concerns for one's career and even safety weren't without foundation. In 1838, Boston Universalist minister turned pantheist Abner Kneeland served two months in jail for expressions of atheism that were judged blasphemous.

It was entirely predictable that, just as Comte was gaining a certain reception among Transcendentalists and the most liberal Unitarians, others attacked Comte for atheism and for denying a role to theology. Thomas Hill, then a Unitarian minister in Waltham, Massachusetts, largely initiated the debate. In reviewing Mill's A System of Logic in the 1846 Christian Examiner, he included a critique of Comte and positivism (Hill 1846). Hill followed with a review of Harriet Martineau's translations, completely dismissing both the Course and the System. ${ }^{21} \mathrm{He}$ took offense at Martineau's claims that

20 Comte to Mill, 14 July 1845, in (Pickering 1993-2009, vol. 2, p. 349). See further the discussion there.

21 (Hill 1854). See also (Hawkins 1936, pp. 17-18) and (Cashdollar 1989, p. 110). 
Comte essentially invented scientific epistemology and that Comte's is the only approach to religion. He then rejected "in toto" (Hill 1846, p. 366; H's emphasis) Comte's "fictitious law of three successive stages" of human intellectual development (Hill 1846, p. 370), his claims to having structured the sciences, and his assertion that he is not necessarily an atheist just because he believes that there is no available proof of God. "While professing to hold Atheism and Theism in equal contempt, as states of mind which he has outgrown, he nevertheless continually renews the statement that the discovery of the laws of science excludes the belief in God. If this be not Atheism, there is no so such phase of mind possible" (Hill 1846, p. 371). Hill later became president of Harvard (1862-1868), and it was probably he who chastised then undergraduate John Fiske in 1862 for expressing support for Comte's views (below).

James Walker, also a future president of Harvard, was among the most free-thinking of traditional Unitarians. Over two years (1841-1843) Walker delivered thirty-six public lectures on natural religion for the Lowell Institute in Boston. Lamentably, the lectures no longer survive, but they were reported on by local newspapers, and Walker himself later published an article in the Christian Examiner which may well reflect his earlier sentiments. In the newspaper accounts, knowledge of and some agreement with Comte is evident. Walker suggested that the religious impulse had evolved through the historical stages that Comte had set forth (fetishism, polytheism, monotheism), but, unlike Comte, he still believed that religious theology had purpose and insight (Hawkins 1936, pp. 16-17; Cashdollar 1989, pp. 98-100). And certainly by the time of his 1849 Christian Examiner article, Walker is decidedly critical. Referring to Comte as "the learned and ingenious founder and expositor of the so-called positive philosophy," he adds that, "Whoever adopts this solution of the problem must hold ... that religion, as well as metaphysics, is destined to die a natural death;- - not by being denied and confuted, but by being ignored; not by the answer given to religious questions, but by the fact that the time is coming when no religious questions will be asked." Indeed, religion

is a hundredfold more in danger from this [positivist] quarter, than from transcendentalism or pantheism. At any rate, the question on the merits of this system, with its corollary in respect to the ultimate fate of all religions, is now an open question; we cannot avert the discussion, if we would; - a discussion which must be expected to hold a prominent place in the controversies of the next fifty years (Walker 1849, pp. 255-56).

Walker comments reflect the degree to which Comte dominated discussion of religion in mid-century eastern Massachusetts. Unitarian minister Orville Dewey recounted to friend and fellow Unitarian clergy Henry W. Bellows that reading the six volumes of the Course in 1845 was "the most serious and terrible business of my existence" (Cashdollar 1989, p. 100, n. 22). Unitarians were clearly worried.

A passing blow was delivered by C.A. Bartol, later a member of the Radical Club (see part 2), in 1851. Reviewing approvingly a book which assumed the supernatural presence of God and Christ, Bartol briefly alluded to Comte's positivism, asserting that, instead, "The truths of religion are not, or they are but very partially, the deductions of natural science" (Bartol 1851, p. 346). Harvard professor Francis Bowen-who had been criticizing Transcendentalism since the 1830s as a manifestation of Platonic paganism - weighed in more directly, publishing in 1854 a harsh criticism of Harriet Martineau's translation of Comte, both invoking gender stereotypes of Martineau and claiming the French philosopher was an atheist. Bowen's criticisms of Comte's purported atheism was followed in 1858 by those of Andrew Preston Peabody, then a Unitarian minister is New Hampshire, but soon to become a professor of Christian morals at Harvard. ${ }^{22}$ Later, with the resignation of the ailing Thomas Hill, Peabody became acting president of Harvard, and a year later, as Phi Beta Kappa orator at Amherst, delivered a far more extensive attack, labeling positivism "an entirely extra-Christian heresy." It is "our besetting danger of the present moment. It has made large and rapid inroads" and younger

22 (Bowen 1854; Peabody 1858a); see also (Hawkins 1938, pp. 23-25, 39-44, 70-72, 86-87; Cashdollar 1989, pp. 110-11). 
scientists especially "are doing all that man can do to legislate God out of his creation" (Peabody 1867, pp. $4,8,18$ ). Yet Peabody's opinions were savaged publicly by prominent intellectuals John Fiske and Chauncey Wright; Fiske's criticisms even helped defeat Peabody's candidacy to be the permanent president of Harvard (Pearce 2015, pp. 452-53). (On Fiske, below.)

To be sure, there was both embrace of and resistance to Comte expressed by members of other denominations. ${ }^{23}$ Academics outside of eastern Massachusetts were mostly hostile. The Reverend Oliver S. Munsell, professor and later president of Wesleyan University of Illinois, published an attack in 1854 (Hawkins 1938, pp. 44-48, 81-82); the Reverend Charles Woodruff Shields, soon to be professor of the harmony of science and religion at the College of New Jersey (Princeton) published his criticisms in 1858 (Hawkins 1938, pp. 48-53); and Francis Wharton, professor of logic and rhetoric at Kenyon College offered his in 1859 (Hawkins 1938, pp. 53-58, 82-86). But there was far disproportional interest in New England, and especially among Unitarians-three of whom, all critics of Comte, eventually becoming president of Harvard College.

While opposition to Comte was manifest before the Civil War, the attacks seem to magnify around the year 1871, as distinguished academics used highly public venues to declare their concerns. John Bascom, then professor at Williams College and in three years' time president of the University of Wisconsin, gave the Lowell lectures in Boston in 1871. Bascom began by ridiculing Comte's Religion of Humanity:

Having banished the Omnipotent One from philosophy, he proceeds to occupy the vacant place with an invention of his own ... If anything is at once absurd, pitiful, strange, instructive, it is this prince in the school of modern, materialistic thought, whose intellectual radiance is spread through a larger circle of Englishmen-men and women, first commanding attention, astonishment and admiration by the peremptory, positive way in which he turns his back on the Christian system, and then providing for his bewildered disciples, the above private theatricals, in which the farce so outweighs the tragedy as to make gravity impossible. ${ }^{24}$

In the same year, Yale president Noah Porter gave the Phi Beta Kappa address at Harvard, arguing that the greatest intellectual question of the day was the conflict between Christianity and positivism (Porter 1871, p. 34). Later, Porter expressed concern that his Yale faculty colleague and America's first sociologist, William Graham Sumner, would use positivist Herbert Spencer's First Principles and Psychology in his undergraduate class (the first course on sociology in America), because, Porter claimed, "the use of the book will bring intellectual \& moral harm to the students ... " Sumner eventually tired of the public fight against his own president and withdrew the books from his course (Cashdollar 1989, pp. 174-75).

James McCosh, president of the College of New Jersey (later Princeton), gave the 1871 Ely lectures at the Union Theological Seminary in New York. McCosh offered a thorough attack on positivism, with which he associated Comte, Mill, and Spencer. The central error of all three philosophers was that they deny the possibility of a positive proof for the existence of God. And although "an open and rabid atheist," of the three "Comte is the most original thinker; but is, throughout, narrow, one-sided, dogmatic..." And yet, while, "His direct influence has all along been very small, being confined to those who had the courage to read through his ponderous volumes ... his indirect influence, through eminent men who followed his method and caught his spirit, has been very great" (McCosh 1875, pp. 167, 172). McCosh here offers important witness to the nature of Comte's influence: it is "indirect" and reflected in "eminent men," confirming Hollinger's "communities of discourse."

23 Henry Charles Carey wrote Principles of Social Science (1858-1859) which was highly influential in its day and which praised Comte's Course: (Hawkins 1938, pp. 87-90). Attacked by College of New Jersey (later Princeton) faculty Lyman Hotchkiss Atwater: (Atwater 1856); and by ( 1857). See more in (Cashdollar 1989, pp. 112-41), especially on Congregational and Baptist responses.

24 (Bascom 1871, pp. 13, 15). See also (Cashdollar 1989, p. 170, and now: Hoeveler 2016, pp. 26-27). 
The following year, the 1872 Ingham Lectures at Ohio Wesleyan entitled A Course on the Evidence of the Evidences of Natural and Revealed Religion afforded an opportunity for speakers to allude to topical subjects. The president of Drew University, the Reverend Randolph S. Foster, named David Friedrich Straus, Renan, Hegel and Comte as the newest threats to Christianity, and Comte, along with Thomas Henry Huxley and Darwin as denying the need for a god to explain the origins and order of the universe (Foster 1872, pp. 7, 19). In his contribution to the volume, the Reverend Asa Mahan, founding president of Oberlin College and then president of Adrian College, included Comte with the likes of Emerson, Spencer, and Mill as the "anti-theists" who deify themselves and science rather than God (Mahan 1872, p. 127).

John W. Mears offered his inaugural address as professor of Hamilton College in 1871 with a talked entitled, "The Antagonisms, Perils and Glory of the Spiritual Philosophy," pronouncing that "the great antagonist of the spiritual philosophy is the immensely aroused scientific interest of our day." He focused his criticisms squarely on Comte (Mears 1871, p. 600). Similar, if less publicly visible lectures occurred especially along the northeastern United States during these years (Cashdollar 1989, pp. 170-71). Around the same time, college student notebooks began reflecting pedagogical interest in Comte (Cashdollar 1989, p. 172, n. 66 references archival material).

Surely, there is something remarkable about so many prominent American academics lining up at the same time to attack publicly a French sociologist whose utopian vision could not conceivably find a home in the United States. It might be possible to apply Foucauldian discursive analysis to this phenomenon. But this appears to be less about control over their listeners than about how elites gave vent to their own anxiety for events beyond their control. These intellectuals formed their own community of discourse. How and why such a community arose at this particular moment admits of several explanations. Exploring the various reasons will help in establishing in part two of this investigation why later Transcendentalists and other post-Unitarians, even while perhaps unconsciously accepting parts of it, became public critics of Comte's positivism.

In simplest terms, of course, there was the progression from the first wave of active intellectuals who had attacked positivism by writing about it in professional journals to the later recognition in the 1870s that positivism was now widely enough known to a general audience that they could talk about it. So great an evolution to broad public engagement is attributable in part to the resonance of other post-war social questions. This was also the time of extensive debate around the Fourteenth Amendment (ratified in 1867) and Fifteenth Amendment (ratified in 1870) and the Suffrage movement. Race and gender remained deeply destabilizing issues, and positivism's utopian and cosmopolitan vision was bound to be mixed in with the anxiety caused by these far more tangible matters. All women mentioned in this article embraced aspects of positivism, and there is no evidence of any American woman writing in opposition. Although John Stuart Mill broke with Comte partly because Comte's position on women was less liberal than his own, Comte's vision on issues of race, gender, and cosmopolitanism was certainly more advanced than were those of most contemporaries. Indeed, many British thinkers optimistically saw Comte's System as "intellectual populism" (Kent 1978, p. xiii) and an invitation to significant social change. Most American intellectuals, however, emotionally exhausted by the war and yet still engaged in fundamental political and social debates, were far more leery of anything so radical (Kent 1978, p. xiii).

Several other considerations were at work as well. There was at the time a highly threatening scientific discovery that could, at least superficially, be confused with positivism. Although Darwin produced On the Origin of Species in 1859, the Civil War tended to delay its reception (Hawkins 1997, p. 104; Bowler 2003, p. 179). In broadest strokes, both Comte and Darwin focused on society as an organism, emphasizing not the individual, but the web of social relationships (Kloppenberg 1988, p. 96). Each presaged the impact of the social sciences in the 1880s which emphasized progress through community over the earlier American celebration of the autonomous individual (Leonard 2016, pp. 16-25). As well, Darwin's evolutionary biology challenged belief in an immanent godhead 
and a divinely created moral universe (Croce 1995, pp. 102-4), and, of course, Comte was widely accused of atheism.

However, that is pretty much the end of their similarities. In Comte's third stage, society had evolved as a unified community of thought that now was achieving its ultimate realization; all that remained was to expand the umbrella of social inclusion. Rather than seeing humans as guided by the same laws of nature as was the rest of organic life, human progress for Comte was "always consisting of the increasing ascendancy of our humanity over our animality, according to the double supremacy of our intelligence over our affective inclinations, and the sympathetic instinct over the personal instinct." ${ }^{\prime 25}$ Comte assumed a broad equality of physical and mental faculties among humans who progressed in concert toward this last stage of civilization. This was an essential assumption if Comte was going to believe that his System would produce a stable society and world peace (Hawkins 1997, pp. 52-54). Darwinism, on the other hand, when applied to society tended toward the opposite interpretation. It produced a social Darwinism anticipated by Herbert Spencer, who in 1864 coined the term "survival of the fittest" (Spencer 1864, vol. 1, pp. 444-45) and whose ideas quickly found a home in capitalist America (Bowler 2003, pp. 220-22).

Although to the careful reader there were obviously vast differences between Darwinism—broadly conceived as explanations for both evolutionary biology and social behavior-and positivism, both were an assault on traditional beliefs. While Darwin's theory of evolution ultimately proved far the greater threat to traditional religion, positivism, with the elaborate nonsense set out in the System, was an easier and more concrete target. ${ }^{26}$ Comte, then, may have served as a proxy for anxious traditionalists reacting against the potential implications of Darwinism.

Among Unitarians specifically, attacks on positivism were both intellectual—especially against the liturgical extravaganza demanded by the System — and also sentimental. Earlier Unitarian sentimentality, that had already begun to fade by the Civil War, was over the ambiguous, lingering belief in the literal divinity of Jesus. Although early Unitarians declared their belief in the absolute oneness of the godhead and therefore in Jesus's essential humanity, it had proved difficult to erase completely an emotional connection to their Congregationalist legacy of Trinitarianism. This current post-war, second stage of sentimentality was a natural progression. The first stage was a resistance to the inevitable conclusions that came from dismissing the biblical evidence of Jesus's miracles; the second stage was a persistence in asserting God's very existence against positivist claims that the Bible was a product of an earlier, less scientific consciousness. Eastern Massachusetts elite was a deeply embedded clerisy resistant to any such massive theological transformation.

If they read Comte at all, it was almost certainly in Martineau's abridged translation. And here is what is found there concerning religious leadership:

As for the kind of persons who are to constitute the new spiritual authority, -it is easy to say who they will not be, and impossible to say who they will be ... The future spiritual power will reside in a wholly new class... The advent of this body will be essentially spontaneous, since its social sway can arise from nothing else than the voluntary assent of men's minds to the new doctrines successively wrought out ... (Comte 1853, vol. 2, p. 467).

True to his positivism, Comte leaves open, through the process of trial and error or hypothesis testing, the formation of a future clerisy.

Although some Unitarians approved of the Course, whatever social merit could be found in the System was more than outweighed by its threat to the theological foundations of existing power structures. This helps explain why Comte's positivism enjoyed far greater popularity among non-religious reformers in New York, where it contributed significantly to social progressivism

25 (Hawkins 1997, p. 54), his translation of Cours, VI 837.

26 On opposition to Darwin (Roberts 1988, pp. 32-86). 
(Harp 1995, pp. 71-209). Prominent New York publisher David Croly even had his son Herbert (future founder of The New Republic) baptized in the church of the Religion of Humanity (Kloppenberg 1988, p. 311).

There were other exogenous reasons for attacking Comte. The Civil War was the first modern conflict in America, producing rapid technological improvements and creating a necessarily rigid organization of military and civil authority (Nevins 1971). George M. Fredrickson, in his highly influential The Inner Civil War: Northern Intellectuals and the Crisis of the Union, argued that the Civil War produced a generation of Americans who in "their concept of 'duty' would be defined less in relation to great causes, and more as a matter of doing necessary tasks in an efficient way" (Fredrickson 1993, p. 172). And, if there has been significant reassessment since Fredrickson's first edition in 1965, it has been in an understanding that the organizational forces of society actually began before the war and that the conflict served more to accelerate them (Butler 2006).

Related to this organizational transformation and emphasis on efficiency was the establishment of the social sciences in America, not only as an area of academic study but also as a way of thinking about social improvement. And this had an important impact on the place of religion in American society. As far back as 1832, there was a great divide between those who believed that religion was the essential driving force for ending slavery and those who, conversely, saw the abolitionist movement as helpful in ridding America of established religion (Sinha 2016, pp. 256-65). A somewhat similar desire to replace religion as the most effective instrument of continuous social improvement also played out with the post-war establishment of the social sciences. Founded in Boston in 1865, the American Social Science Association, with the help of Frank Sanborn-a former member of the Secret Six and a marginal member of the Transcendentalists-made amelioration an essential component of academic study and social organization. The ASSA soon founded the National Conference of Charities and Correction, which represented "a concern that regular channels be established by which society would grant authority to those most qualified to hold it ... [and] the cultivation of expertise, within a framework of professional institutions, a way to improve the quality of American life" (Haskell 2000, pp. 60-61). Rather than through volunteer religious organizations, it was now the secular social sciences that were looked to as the essential vehicle for performing social good.

Faced with the challenges of modernity, Unitarians had long taken refuge in their conviction of perfectionism: that social action framed by their liberal and tempered religious belief would inevitably improve secular society. But, as John Thomas observed, "the [Civil W]ar brought with it a widespread reaction against the sentimentality and illusions of [Unitarian] perfectionism" (Thomas 1965, p. 679). The cultural leadership of the established New England clerisy promoting moral, Christian perfectionism was being replaced by bureaucratic approaches to social improvement. And this emerging culture based upon professional expertise that could substitute for the role of traditional religion might again find resonance in parts of Comte's own System. Indeed, from its earliest days, the ASSA, in its flagship publication, Journal of Social Science, acknowledged "the celebrated French philosopher, Auguste Comte" as the founder of sociology (Strong 1871, p. 1). Once again, positivism could be viewed as part of the threat to the religious status quo.

But most importantly, both the inexorable nineteenth century scientific support for Enlightenment philosophical rationalism and the horrors of incessant slaughter in the Civil War produced two opposing reactions that helped dictate response to Comte's purported atheism. One was the evangelical and messianic spirit of the war, ${ }^{27}$ which inspired an especially vivid defense of religion with its promise of divine purpose and reward for sacrifice ("As He died to make men holy, let us die to make men free"). The other, inevitably contrary reaction, was a significant increase in agnosticism tempered only by a vague sense of spirituality. ${ }^{28}$ Comte's apparent denial of anything beyond the social and moral

27 Most recently (Rable 2010, pp. 204-21); also (Schantz 2008), and (Rose 1992, pp. 60-67).

28 (Rable 2010, pp. 240-57); also: (Butler 2007, pp. 136-37; Turner 1985, pp. 171-202). 
utility of secular ritual must have made more traditionally-minded thinkers worry that this was also the end point for the growing number of American agnostics.

The renewed religious fervor combined with anxiety over agnosticism was reflected in significant cultural shifts within the academy. Around 1870, colleges crossed an essential threshold, transitioning from generally functioning as confirming American Protestantism by transmitting established truths founded on natural theology to ones producing knowledge based on objective and scientific inquiry (Roberts and Turner 2000, pp. 19-41). Andrew Dickson White, first president of Cornell, took the lead. His 1869 speech at the Cooper Institute, with the polemical title of "The Battle-Fields of Science," produced heated debate in the pages of the New York Daily Tribune over the primacy of science in higher education. There followed several works which "repudiated the notion that the 'restraints of religion' were necessary for fruitful scientific investigation." White and others pushed for "truth for its own sake" and "blasted Christian theology for restricting untrammeled investigation" (Roberts and Turner 2000, p. 63). It was a time of-in David Hollinger's words-“tonic destruction" of traditional religious practice and belief (Croce 1995, p. 187).

Meanwhile, Charles W. Eliot, a physical scientist at Harvard, gained national prominence for his writings on education, arguing that the traditionally narrow classical education must give way to a broader approach driven by an explicitly Emersonian notion of intellectual self-determination (Eliot 1869, 1901). For his efforts, Eliot was elected president of his university and subsequently turned Harvard into a national institution by professionalizing its academic departments. This meant the formal study of religious thought occurred not just in the Divinity School, but also in philosophy (for example: Francis Bowen and Josiah Royce) and psychology (William James). The greater academicizing of religion must have been a threat to many clergy; indeed, Eliot, himself deeply steeped in New England Unitarianism, went so far as to criticize the practice of making ministers the heads of secular colleges (Reuben 1996, p. 77).

It's little wonder that presidents of other universities, many of whom were, in fact, members of the clergy, took to public venues to denounce Comte. For, positivism could be associated with the secularizing of the academy. Its approach to factual knowledge quickly became an essential part of academic epistemology, and Comte's architecture of knowledge aligned with and even helped establish the emerging academic disciplines. In place of the traditional Aristotelian "Great Chain of Being" that started with the inanimate and ascended to the divine, Comte's structure began with the basic sciences and ended with the study of humankind.

As part of his effort to expand the educational opportunities at Harvard, Eliot hired Chauncy Wright in 1871 to lecture in psychology; and Wright, despite his own denials of interest in Comte's work, was substantially influenced by positivism (Wright 1866; De Groot 2015). But of far greater notoriety, as soon as he became president Eliot appointed John Fiske to give eighteen lectures on positivism, lectures that were also published in the New York World (Pearce 2015, pp. 453-54). Merely seven years previously as a student there, Fiske had been chastised for espousing Comtean philosophy. In his new role, Fiske was sufficiently threatening that alumni resistance helped deny him a permanent appointment. Prominent Unitarian James Freeman Clarke, for example, told Eliot that Fiske should not represent the university, because Comte's positivism "was equivalent to Atheism." 29

At the time of his appointment, Fiske wrote Spencer: "It is worthy of notice that only seven years ago I was threatened with dismissal from the college if caught talking Comtism to anyone. Now ... I am asked to expound Comtism to the college, \& defend or attack it as I like." 30 Since 1850, Spencer, despite his own explicit denials, was associated by much of the public with Comte's positivism (Cashdollar 1989, pp. 145-47). And Fiske is a prime example of someone who incorporated

29 Quoted by (Reuben 1996, p. 134); also (Cashdollar 1989, p. 172). See (Metzer 1961, p. 64, n. 72) for other details about Fiske's failure to be reappointed.

30 Correspondence cited in (Cashdollar 1989, p. 281, n.1). 
both thinkers (Pearce 2015, pp. 445-47), cycling through Comte to Spencer. ${ }^{31}$ Fiske began calling positivism Cosmism-a clever allusion to Comte mixed with his own approach which he called Cosmic Philosophy. Unlike Allen, Fiske needed an Aristotelian-like First Cause, something beyond reliance on the phenomenal to understand how the cosmos came into being and continued to harmonize. Indeed, Darwin's evolutionary biology sent Fiske in an unexpected direction. Rather than seeing it as an argument for godlessness or at least a distant and transcendent god, he began to believe that evolution, so elegantly deterministic, must have divine elements; hence his own theism necessarily admitted of something anthropomorphic:

It is quite true, on the one hand, that to ascribe what we know as human personality to the infinite Deity straightway lands us in a contradiction, since personality without limits is inconceivable. But on the other hand, it is no less true that the total elimination of anthropomorphism from the idea of God abolishes the idea itself (Fiske 1890, p. 135).

But this statement is taken from a later work, part of one of the final stages in Fiske's constantly evolving theology. Earlier, in 1874, he produced Outlines of Cosmic Philosophy. There, while tending more toward Spencer, he remained largely in agreement with Comte on his law of three stages with an envisioned world peace through the universal sentiment of altruism, but required the intellectual space to admit the existence of "our ineradicable belief in the absolute existence of Something which underlies and determines the series of changes which constitutes our consciousness." 32

Fiske's own intellectual odyssey reflects how Comte's work might serve as inspiration for spiritual exploration after the Civil War. Most reactions to Comte, however, were negative, as criticizing positivism proved a convenient method for addressing a broad range of anxieties in a country that, having just survived an existential crisis, continued to confront astonishingly rapid social, technological, and scientific change. Painting on so large a canvas, Comte inevitably touched on-if he did not always actually help create-the very forces that produced so many of these anxieties. Comte's most devoted biographer once asked: "How much of the positivist system did someone have to accept to be labeled a positivist?" (Pickering 1993-2009). Conversely, it could also be asked: exactly how much of the positivist system did a critic need to understand for the criticism to be about positivism? Although early Transcendentalists were more careful and therefore constructive in their readings of positivism, later Transcendentalist and post-Unitarian thinkers, perhaps sufficiently influenced by this onslaught of highly public criticism to form their own community of discourse, became far less so. It remains in part two to appreciate how these intellectuals might criticize positivism all the while absorbing some of Comte's vocabulary and beliefs.

Acknowledgments: The author wishes to thank a particularly perceptive and careful referee of both part one and two for many fine criticisms and suggestions.

Conflicts of Interest: The author declares no conflict of interest.

\section{Abbreviation}

$C E=$ The Christian Examiner

\section{References}

Allen, Joseph Henry. 1844. Tendencies of Modern Philosophy. The Christian Examiner 37: 145-70.

Allen, Joseph Henry. 1851. Comte's Positive Philosophy. The Christian Examiner 50: 174-20.

Allen, Joseph Henry. 1857a. Comte's Religion of Humanity. The Christian Examiner 63: 18-36.

Allen, Joseph Henry. 1857b. Review of Current Literature. The Christian Examiner 63: 437.

Allen, Joseph Henry. 1880. The Religion of Humanity. Unitarian Review and Religious Magazine 14: 51-60.

31 Certainly by 1874: (Roberts 1988, pp. 70-72).

32 (Fiske 1874, pp. 106-7); also (Kuklick 1977, p. 85); on his belief in altruism, (Hawkins 1997, p. 107). 
Allen, Joseph Henry. 1882. Our Liberal Movement in Theology. Boston: Roberts Brothers.

Allen, Joseph Henry. 1891. Positive Religion: Fragments, and Hints. Boston: Roberts Brothers.

Ampère, Jean-Jacques. 1855. Promenades en Amérique: États-Unis-Cuba-Mexique. 2 vols.; Paris: Michel Lévy Frères. Anonymous. 1857. Comte's Positive Philosophy. Presbyterian Quarterly Review 6: 311-31.

Atwater, Lyman Hotchkiss. 1856. The Positive Philosophy of Auguste Comte. Biblical Repertory and Princeton Review 28: 59-88.

Bartol, Cyrus Augustus. 1851. Christian Consolations. Sermons Designed to Furnish Comfort and Strength to the Afflicted by A. P. Peabody. North American Review 72: 343-57.

Bascom, John. 1871. Science, Philosophy and Religion: Lectures Delivered before the Lowell Institute, Boston. New York: G. P. Putnam \& Sons.

Berlin, Isaiah. 1954. Historical Inevitability. London: Oxford University Press.

Bourdeau, Charles. 2014. Auguste Comte. Available online: http://plato.stanford.edu/entries/comte/ (accessed on 1 June 2017).

Bowen, Francis. 1854. Martineau's Translation of Comte's Philosophy. North American Review 79: 200-29.

Bowler, Peter J. 2003. Evolution: The History of an Idea, 3rd ed. Berkeley: University of California.

Butler, Leslie. 2006. Reconstructions in Intellectual and Cultural History. In Reconstructions: New Perspectives on Postbellum United States. Edited by Thomas Brown. New York: Oxford.

Butler, Leslie. 2007. Critical Americans: Victorian Intellectuals and Transatlantic Liberal Reform. Chapel Hill: University of North Carolina Press.

Capper, Charles. 1998. 'A Little Beyond': The Problem of the Transcendentalist Movement in American History. The Journal of American History 85: 502-39. [CrossRef]

Cashdollar, Charles. 1989. The Transformation of American Theology, 1830-1890: Positivism and Protestant Thought in Britain and America. Princeton: Princeton University Press.

Comte, Auguste. 1822. Plan des travaux scientifiques nécessaires pour réorganiser la société. In Suite des Travaux Ayant Pour Objet de Fonder le Système Industriel, du Contrat Social, Par Saint-Simon, Prospectus des Travaux Scientifiques Nécessaires Pour Réorganiser la Société, Par Auguste Comte. Paris: Unidentified Publisher.

Comte, Auguste. 1830-1842. Cours de Philosophie Positive. 6 vols.; Paris: Rouen.

Comte, Auguste. 1851-1854. Système de Politique Positive, ou Traité de Sociologie Instituant la Religion de l'Humanité. 4 vols.; Paris: Carilian-Goeury.

Comte, Auguste. 1852. Catéchisme Positiviste. Paris: Self-Published.

Comte, Auguste. 1853. The Positive Philosophy of Auguste Comte Freely. Translated and Condensed by Harriet Martineau; 2 vols.; New York: D. Appleton and Co.

Comte, Auguste. 1975. Auguste Comte and Positivism: The Essential Writings. Edited and Introduction by Gertrud Lenzer; Chicago: University of Chicago Press.

Croce, Paul Jerome. 1995. Science and Religion in the Era of William James. Volume 7: Eclipse of Certainty, 1820-1880. Chapel Hill: University of North Carolina Press.

Davies, Charles Maurice. 1876. Unorthodox Places; or, Phases of Religious Life in the Metropolis, 2nd ed. London: Tinsley Brothers.

De Groot, Jean. 2015. Chauncey Wright. Available online: https://plato.stanford.edu/entries/wright/ (accessed on 1 June 2017).

Edwin, John. 1931. A Crusade for Humanity: The History of Organized Positivism in England. London: Watts \& Co.

Eliot, Charles W. 1869. The New Education Parts 1 and 2. Atlantic Monthly 23: 203-21.

Eliot, Charles W. 1901. Inaugural Address as the President of Harvard College, October 19, 1869. In Educational Reform: Essays and Addresses. Edited by Charles W. Eliot. New York: The Century Co., pp. 1-40.

Emerson, Ralph Waldo. 1990. The Letters of Ralph Waldo Emerson. Edited by Eleanor M. Tilton. New York: Columbia University Press, Volume 7, pp. 1807-1844.

Fiske, John. 1874. Outlines of Cosmic Philosophy: Based on the Doctrine of Evolution, with Criticisms of the Positive Philosophy. Boston: Houghton Mifflin Company.

Fiske, John. 1890. The Idea of God as Affected by Modern Knowledge. Boston: Houghton Mifflin.

Forbes, Geraldine Hancock. 1975. Positivism in Bengal. Calcutta: Minerva.

Foster, Randolph S. 1872. Personal Cause. In A Course on the Evidence of the Evidences of Natural and Revealed Religion. Edited by William A. Ingham. Cleveland: Ingham, Clark and Co., pp. 3-38. 
Fredrickson, George M. 1993. The Inner Civil War: Northern Intellectuals and the Crisis of the Union. Urbana-Champaign: Illini Press.

Frothingham, Octavius Brooks. 1886. Memoir of William Henry Channing. Boston: Houghton Mifflin.

Gilman, Samuel. 1830. Unitarian Christianity free from Objectional Extremes. CE 8: 133-46.

Gottlieb, Anthony. 2016. Who Was David Hume? New York Review of Books 68: 70-71.

Greene, John C. 1969. Biology and Social Theory in the Nineteenth Century: Auguste Comte and Herbert Spencer. In Critical Theories in the History of Science. Edited by Marshall Clagett. Madison: University of Wisconsin Press, pp. 419-46.

Grodzins, Dean. 2002. American Heretic: Theodore Parker and Transcendentalism. Chapel Hill: University of North Carolina Press.

Gura, Philip F. 2017. Man's Better Angels: Romantic Reformers and the Coming of the Civil War. Cambridge: Harvard University Press.

Hale, Charles A. 1989. Transformation of Liberalism in Late 19th Century Mexico. Princeton: Princeton University Press.

Harp, Gillis. 1995. Auguste Comte and the Reconstruction of American Liberalism, 1865-1920. University Park: Pennsylvania State University Press.

Haskell, Thomas. 2000. The Emergence of the Professional Social Sciences in the United States: The American Social Science Association and the Nineteenth-Century Crisis of Authority. Urbana: University of Illinois Press.

Hawkins, Richard Lauren. 1936. Auguste Comte and the United States (1816-1853). Cambridge: Harvard University Press. Hawkins, Richard Lauren. 1938. Positivism in the United States (1853-1861). Cambridge: Harvard University Press. Hawkins, Mike. 1997. Social Darwinism in European and American Thought, 1860-1945: Nature as Model and Nature as Threat. Cambridge: Cambridge University Press.

Hill, Thomas. 1846. Fundamental Laws of Reasoning. CE 40: 363-84.

Hill, Thomas. 1854. Miss Martineau's Compend of Comte's Positive Philosophy. CE 56: 364-72.

Hoeveler, J. David. 2016. John Bascom and the Origins of the Wisconsin Idea. Madison: University of Wisconsin Press.

Hollinger, David. 1980. Historians and the Discourse of Intellectuals. In New Directions in American Intellectual History. Edited by John Higham and Paul Keith Conkin. Baltimore: Johns Hopkins Press.

Hunter, Doreen. 1980. Frederic Henry Hedge: What Say You? American Quarterly 32: 186-201. [CrossRef]

Hurth, Elisabeth. 2007. Between Faith and Unbelief: American Transcendentalists and the Challenge of Atheism. Leiden: Brill.

Kent, Christopher. 1978. Brains and Numbers: Elitism, Comtism, and Democracy in Mid-Victorian England. Toronto: University of Toronto Press.

Kloppenberg, James T. 1988. Uncertain Victory: Social Democracy and Progressivism in European and American Thought, 1870-1920. New York: Oxford University Press.

Kuklick, Bruce. 1977. The Rise of American Philosophy, Cambridge, Massachusetts, 1860-1930. New Haven: Yale University Press.

Leonard, Thomas C. 2016. Illiberal Reformers: Race, Eugenics \& American Economics in the Progressive Era. Princeton: Princeton University Press.

Mahan, Asa. 1872. Theism and Antitheism in their Relations to Science. In A Course on the Evidence of the Evidences of Natural and Revealed Religion. Edited by William A. Ingham. Cleveland: Ingham, Clark and Co., pp. 109-35.

Marx, Karl, and Friedrick Engels. 1975. Selected Correspondence. Translated by I. Lasker. Moscow: Progress Publishers.

McCosh, James. 1875. Christianity and Positivism: A Series of Lectures to the Times on Natural Theology and Apologetics. London: Macmillian.

McGee, John Edwin. 1931. A Crusade for Humanity: The History of Organized Positivism in England. London: Watts \& Co.

Mears, John W. 1871. The Antagonisms, Perils and Glory of the Spiritual Philosophy. American Presbyterian and Theological Review 3: 597-627.

Metzer, William P. 1961. Academic Freedom in the Age of the University. New York: Columbia University Press.

Mill, John Stuart. 1848. On Liberty and Considerations on Representative Government. Edited by R.B. McCallum. Oxford: Basil Blackwell.

Mill, John Stuart. 1865. Auguste Comte and Positivism. London: N. Trübner \& Co.

Nevins, Allan. 1971. The War for the Union, Vol. 4: The Organized War to Victory, 1864-1865. New York: Charles Scribner's Sons. 
Parker, Theodore. 1865. A Discourse of Matters Pertaining to Religion, 4th ed. Boston: R. Leighton.

Parker, Theodore. 1867. Sermons of Theism, Atheism, and the Popular Theology, 2nd ed. London: N. Trübner \& Co.

Peabody, Andrew Preston. 1858a. Reviewed of "Work(s): Republic of the West. Order and Progress. The Catechism of Positivism; Or, Summary Exposition of the Universal Religion. In Thirteen Systematic Conversations between a Woman and a Priest of Humanity? by Auguste Comte and Richard Congreve. North American Review 87: 268-69.

Peabody, Elizabeth Palmer. 1858b. The Being of God. The Christian Examiner 65: 239-48.

Peabody, Andrew Preston. 1867. The Positive Philosophy. Boston: Gould and Lincoln.

Pearce, Trevor. 2015. 'Science Organized': Positivism and the Metaphysical Club, 1865-1875. Journal of the History of Ideas 76: 441-65. [CrossRef] [PubMed]

Peirce, Charles S. 1896. The Regenerated Logic. Monist 7: 19-40. [CrossRef]

Pickering, Mary. 1993-2009. Auguste Comte: An Intellectual Biography. 3 vols.; Cambridge: Cambridge University Press.

Plé, Bernhard. 1996. Die"Welt" aus den Wissenschaften: Der Positivismus in Frankreich, England und Italien von 1848 bis ins zweite Jahrzent des 20. Jahrhunderts. Stuttgart: Klett-Cotta.

Porter, Noah. 1871. The Sciences of Nature versus the Science of Man: A Plea for the Science of Man. New York: Dodd \& Mead.

Rable, George C. 2010. God's Almost Chosen Peoples: A Religious History of the Civil War. Chapel Hill: University of North Carolina Press.

Reuben, Julie A. 1996. The Making of the Modern University: Intellectual Transformation and the Marginalization of Morality. Chicago: University of Chicago Press.

Roberts, Jon H. 1988. Darwinism and the Divine in America: Protestant Intellectuals and Organic Evolution, 1859-1900. Madison: University of Wisconsin Press.

Roberts, Jon H., and James Turner. 2000. The Sacred and the Secular University. Princeton: Princeton University Press.

Rose, Anne C. 1992. Victorian America and the Civil War. Cambridge: Cambridge University Press.

Santayana, George. 1913. The Genteel Tradition in American Philosophy. In Winds of Doctrine. New York: Charles Scribner's Sons.

Schantz, Mark S. 2008. Awaiting the Heavenly Country: The Civil War and America's Culture of Death. Ithaca: Cornell University Press.

Simon, Walter Michael. 1963. European Positivism in the Nineteenth Century. New York: Kennicat Press.

Sinha, Manisha. 2016. The Slave's Cause: A History of Abolition. New Haven: Yale University Press.

Spencer, Herbert. 1864. Principles of Biology. London: Williams and Norgate.

Strong, William. 1871. The Study of Social Science. Journal of Social Science 4: 1-8.

Thomas, John L. 1965. Romantic Reform in America, 1815-1865. American Quarterly 17: 656-81. [CrossRef]

Trindade, S. 2003. La république positiviste chez Comte, théorie et pratique. In Auguste Comte, Trajectoires positivistes 1798-1998. Edited by Annie Petit. Paris: L'Harmattan, pp. 363-83.

Turner, James. 1985. Without God, Without Creed: The Origins of Unbelief in America. Baltimore: The Johns Hopkins Press. Walker, James. 1849. The Philosophy of Religion. The Christian Examiner 47: 247-68.

Weiss, John. 1864. Life and Correspondence of Theodore Parker. New York: D. Appleton \& Company.

Wernick, Andrew. 2000. Auguste Comte and the Religion of Humanity: The Post-Theistic Program of French Social Theory. Cambridge: Cambridge University Press.

Williams, George H. 2014. Divinings: Religion at Harvard: from Its Origins in New England Ecclesiastic History to the 175th Anniversary of the Harvard Divinity School, 1636-1992. 3 vols.; Edited by Rodney Lawrence Peterson. Göttingen: Vandenhoeck \& Ruprecht.

Wright, Chauncey. 1866. Mill on Comte. Nation 21: 20-21.

Wright, Chauncey. 1878. Letters of Chauncey Wright; with Some Account of His Life. Edited by James Bradley Thayer. Cambridge: John Wilson and Son.

(C) 2017 by the author. Licensee MDPI, Basel, Switzerland. This article is an open access article distributed under the terms and conditions of the Creative Commons Attribution (CC BY) license (http://creativecommons.org/licenses/by/4.0/). 